Journal Ability : : Journal of Education and Social Analysis

Volume 2, Issue 3, Juli 2021

\title{
Teknik-Teknik Dan Pengambilan Keputusan Birokrasi Dan Peran Etika
}

\author{
Mayasari \\ Universitas Islam Negeri Sumatera Utara Medan
}

Corresponding Author : mayya180490@gmail.com

\begin{tabular}{ll}
\hline & \multicolumn{1}{c}{ ABSTRACT } \\
\cline { 2 - 3 } & $\begin{array}{l}\text { Teknik dan pengambilan keputasan adalah sentral dan stategis. Salah } \\
\text { satunya fungsi manajemen, biasanya gaya kepemimpinan yang dimiliki } \\
\text { oleh pemimpin ada beberapa yang sering menjadi pola dalam }\end{array}$ \\
& $\begin{array}{l}\text { pengambilan keputusan. Dalam pengambilan keputusan herus } \\
\text { mempunyai etika dan moral. Dengan demikian maka fungsi etika adalah } \\
\text { untuk membina kehidupan yang baik berdasarkan nilai-nilai moral } \\
\text { tertentu. Kehidupan manusia bersifat multi dimensi meliputi berbagai } \\
\text { bidang sosial, ekonomi, politik, kebudayaan yang semuanya memerlukan } \\
\text { etika termasuk didalamnya kehidupan birokrasi. Uraian berikut mencoba } \\
\text { menelusuri jejak birokrasi di Indonesia. memahami nilai-nilai yang }\end{array}$ \\
& $\begin{array}{l}\text { terkandung didalamnya dan bagaimana perilaku birokrasi kita dalam } \\
\text { menyongsong masa depan. }\end{array}$ \\
\cline { 2 - 3 } Kata Kunci & Teknik, Etika, Birokrasi \\
\cline { 2 - 3 } How to cite & (2021). Jurnal Ability, 2(3). \\
\cline { 2 - 3 } &
\end{tabular}

\section{PENDAHULUAN}

Setiap masyarakat atau bangsa pasti mempunyai pegangan moral yang menjadi landasan sikap, perilaku dan perbuatan mereka untuk mencapai apa yang dicita-citakan. Dengan pegangan moral itu dibedakan mana yang baik, dan mana yang buruk, benar dan salah serta mana yang dianggap ideal dan tidak. Oleh karena itu dimana pun kita bermasyarakat, berbangsa dan bernegara peranan etika tidak mungkin dikesampingkan Semua warganegara berkepentingan dengan etika.

Dalam kenyataan kehidupan sosial semua masyarakat mempunyai atuan moral yang membolehkan atau melarang perbuatan tertentu. Tata kelakuan itu harus diikuti oleh anggota masyarakat dan akan menimbulkan hukuman bagi pelanggarnya. Namun bisa sebaiknya yang terjadi apabila perilaku yang dilaksanakan dianggap ideal maka akan mendapat imbalan (reward) yang sesuai. Dengan demikian maka fungsi etika adalah untuk membina kehidupan yang baik berdasarkan nilai-nilai moral tertentu. Kehidupan manusia bersifat multi dimensi meliputi berbagai bidang sosial, ekonomi, politik, kebudayaan yang semuanya memerlukan etika termasuk didalamnya kehidupan birokrasi. 
Ability : Journal of Education and Social Analysis

Volume 2, Issue 3, Juli 2021

Page : $30-40$

Kalau dikaitkan dengan pembangunan maka etika sangat erat fungsinya dan menyatu dengan kegiatan pembangunan. Apa saja yang dilakukan demi mencapai taraf hidup yang lebih baik, melekat peranan etika. Sistem dan prosedur yang berlaku dalam pembangunan, sarat dengan nilai-nilai moral yang hams dipegang teguh oleh mereka yang teriibat dalam pembangunan. Apa yang kita laksanakan dalam pembangunan pada hakekatnya adalah dari, oleh, dan untuk manusia atau 'people centered development'.Dalam rumusan Garis-Garis Besar Haluan Negara (GBHN disebut pembangunan manusia seutuhnya dan masyarakat Indonesia seluruhnya. Dalam pembangunan yang demikian diusahakan keseimbangan pembangunan fisik materiil dan mental spiritual dan ruang cakupannya meliputi seluruh masyarakat bangsa Indonesia. Uraian berikut mencoba menelusuri jejak birokrasi di Indonesia. memahami nilai-nilai yang terkandung didalamnya dan bagaimana perilaku birokrasi kita dalam menyongsong masa depan.

\section{METODOLOGI PENELITIAN}

Penelitian ini menggunakan studi kepustakaan (library research). Dalam memperoleh data penelitian, peneliti mengumpulkan, menganalisis, mengorganisasi, sumber dari artikel, buku, penelitian terdahulu tentang implementasi manajemen strategi dalam bidang pendidikan. Kemudian peneliti menyimpulkan dan menyajikan data-data manajemen strategi untuk peningkatan mutu pendidikan (Danandjaja, 2014; Sari \& Asmendri, 2020; Zed, 2014).

\section{HASIL PENELITIAN DAN PEMBAHASAN}

\section{A. Teknik Dan Alat Pengambilan Keputusan}

Harrison (1990 ) menjelaskan bahwa dalam menetapkan keputusan dikenal teori probabilitas, utilitas, dan permainan. Teori utilitas dilandasi dengan pertanyaan, seberapa manfaat yang dapat diperoleh dari sebuah solusi atas persoalan ?. Adapun teori permainann ketika seorang pengambil kebijakan tidak terlampau memahami keadaan ketika sebuah keputusan diambil.

Sebuah keputusan dapat bermanfaat atau tidak bisa dilihat dengan poin sebagai berikut :

- Adanya sumber daya organisasi

- Adanya sumber daya manusia

- Memiliki budaya kerja tim

- Mengakomodasi aspirasi

- Efesiansi dalam oprasional 
Ability : Journal of Education and Social Analysis

Volume 2, Issue 3, Juli 2021

Page : $30-40$

Ketika mengambil keputusan dapat menggunakan alat bantu, sedangkan alat bantu yang dapat digunakan sebagai berikut :

Pertama, jika untuk kepuusan rutin dapat menggunakan : standar operasi, artificial intelligence yang bekerja otomatis. Kedua, jika untuk keputusan adaptif biasanya dapat memakai : analisis titip impas, yaitu biaya total penjualan sama dengan total uang yang dikeluarkan untuk produksi : biaya tetap. Biaya variable, total penerimaan, profit, rugi, dan titik impas.

\section{B. Analisis Dan Teknik Pengambilan Keputusan Kreatif}

Berikut adalah teknik yang dapat digunakan dalam mengambil keputusan.

- Analisis diagram pareto ( pareto analysis). Analisis pareto bertujuan mencari perubahan mendasar bagi pengambilan keputusan. Melalui analisis pareto dapat dilihat kondisi persoalan yang harus diselesaikan dan dapat menampilkan seberapa derajat kerumitan sebuah masalah.

- Analisis jaringan sebuah analisis yang akan membantu para pembuat keputusan memilih alternative dengan mempertemukan berbagai faktor yang ada.

- Analisis persoalan, manajer mengurai permasalahan sehingga dapat menyingkirkan data yang tidak diperlukan. Tahap yang dilakukan sebagai berikut :

a. Merumuskan masalah, menyatakan apa saja hal yang dipersoalkan

b. Memerinci masalah, memperjelas secara detail identitas masalah.

c. Memberi data relevan, apa penyebabnya agar dapat dicari solusi masalah.

d. Mencari sebab-sebab, agar dapat apa yang paling memungkinkan.

e. Vertifikasi, bagi sebab yang paling mungkin.

- Analisis keputusan, dilandasi pemikiran strategis memutuskan solusi. Tahap yang dapat dilakukan :

a. Perumusan pernyataan keputusan, dirumuskan dengan memperhatikan sumber daya organisasi.

b. Mengembangkan berbagai alternative agar lebih banyak pilihan.

c. Memperhitungkan konsekuensi setiap pilihan yang diputuskan.

- Analisis potensial, prinsip yang digunakan lebih baik memcegah masalah daripada mencari solusi justru membuat masalah semakin parah. Secara ringkas langkah yang dilakukan sebagai berikut:

a. Mengenal daerah yang rawan dan kritis terkena masalah.

b. Memprediksi apa yang akan terjadi di daerah rawan sehingga dapat ditentukan skala prioritas. 
Page : $30-40$

c. Mengenal penyebab masalah dan merancangbagaimana mencegahnya.

d. Melakukan aktivitas penanggulangan masalah.

\section{Sistem Informasi Dalam Proses Perencanaan Keputusan}

Margaret A. Rathwell dan Alan Burs menganjurkan kepada pengambilan keputusan. Di era 4.0 sekarang, sangat tidak mungkin menghindari teknologi informasi dan era digital agar dapat bermanfaat dalam merumuskan keputusan. Awalnya penggunaan teknologi informasi dikenal dengan sistem informasi manajemen kemudian berkembang menjadi sistem pendukung keputusan. Terdapat juga distributed decision making (DDM) sebagai mekanisme berintraksi didalam organisasi.

Decision Support System (DSS). DSS muncul pada tahun 1971 oleh G. Anthony Gorry dan Michel S.Scott Morton dikarenakan menangani persoalan yang tidak terstruktur dab bersifat baru. Gorry dan Scott membangu sebuah perangkat guna menyelesaikan masalah tidak terstruktur dan tingkatan manajemen. DSS dirancang mendukung pengambilan keputusan, maka sistemnya harus :

- Simple

- Mudah dikendalikan

- Otomatis

- Adaptif

- Memiliki fiktur yang lengkap

- Mudah menggunakannya. Sangat jelas bahwa ini menggunakan computer dan ternologi informasi

Keunggulan dari DSS sebagai berikut :

a. Mendukung keputusan dengan pemaduan potensi manusia dan teknologi informasi.

b. Berbagai level manajerial memeroleh dukungan.

c. Adanya keputusan yang sistematis

d. Melewati proses tahapan pengumpulan data, perancangan bangun, pilihan dan pelaksanaan, cocok dengan gaya keputusan yang beragam

e. Individu bisa membuat keputusan

f. Dapat beradaptasi dengan perkembangan zaman, sehingga dapat menambahkan dab mengurangi fitur yang dibutuhkan dan dianggap tidak diperlunjak lagi

g. Analisis diberikan tepat waktu 
Ability : Journal of Education and Social Analysis

Volume 2, Issue 3, Juli 2021

Page : $30-40$

h. Mengutamakan efaktifitas berbentuk keakuratan daripada efisien yang terkait pendanaan

i. Bertujuan membantu bukan untuk menggantikan peran manusia

j. Membuat organisasi menjadi pembelajar agar terus dapat berkembang

k. Dapat menggunakan sistem yang lebih luas

1. Adanya pemodelan

m. Dapat menyelesaikan masalah rumit

DSS akan bermanfaat bagi organisasi sebagaimana dijelaskan dalam poin sebagai berikut :

a. Ekspensi kecakapan dalam pengambilan keputusan

b. Masalah tidak berstruktur bisa diberi solusi

c. Diperoleh solusi yang cepat dan tepat

d. Merangsang pembuat keputusan untuk memahami permasalahan.

Dari penjelasan diatas, dapat dipahami bahwa DSS bertugas untuk mempermudah pembuat keputusan, bukan untuk menggantikannya. Organisasi tetap memiliki personel andal dalam merumuskan keputusan.

\section{Konsep Etika}

Kata etika berasal dari kata ethos(bahasa yunani) yang berarti karakter, watak kesusilaan atau adat. Sebagai suatu subjek, etika berkaitan dengan konsep yang dimiliki oleh individu ataupun kelompok untuk menilai apakah tindakan - tindakan yang telah dikerjakannya itu salah atau benar, buruk atau baik. Etika adalah refleksi dari self control karena segala sesuatunya dibuat dan diterapkan dari dan untuk kepentingan kelompok itu sendiri. Etika disebut juga filsafat moral, cabang dari filsafat yang berbicara tentang tindakan manusia.

Menurut para ahli, etika adalah aturan perilaku, adat kebiasaan manusia dalam pergaulan antar sesamanya dan menegaskan mana yang benar dan mana yang buruk. Etika dalam perkembangannya sangat mempengaruhi perkembangan manusia. Etika memberi manusia orientasi cara ia menjalani hidupnya melalui rangkaian kehidupan sehari - hari. Ada dua macam etika yang harus kita pahami bersama dengan menentukan baik dan buruknya perilaku manusia:

- Etika Deskriptif tingkah laku moral dalam arti luas, seperti adat kebiasaan, anggapan tentang baik dan buruk, tindakan - tindakan yang diperbolehkan.

- Etika Normatif dalam hal ini, sesorang dapat dikatakan sebagai participation approach karena yang bersangkutan telah melibatkan diri dengan mengemukakkan penilaian tentang perilaku manusia. Ia tidak 
Page : $30-40$

netral karena berhak untuk mengatakan atau menolak suatu etika tertentu.

- Metaetika, awalan meta (Yunani), berarti "melebihi", "melampaui". Metaetika bergerak seolah - olah pada taraf lebih tinggi dari perilaku etis, yaitu pada taraf "bahasa etis" atau bahasa yang digunakan dibidang moral. Etika selalu berhubungan dengan hal - hal baik dan buruk, antara hal - hal yang susila dan tidak susila, ataupun antara hal - hal yang tidak boleh dilakukan. Ada beberapa mazhab dalam etika antara lain sebagai berikut:

a. Egoisme, adalah tindakan taua perbuatan memberi hasil atau manfaat bagi diri sendiri untuk jangka waktu selama diperlukan atau dalam waktu yang lama. Egoisme secara praktis tampak dalam aliran berikut: hedonisme, eudaemonisme.

b. Deontologisme, berpendapat bahwa baik-buruknya atau benarsalahnya suatu tindakan tidak diukur berdasarkan akibat yang ditimbulkannya, tetapi berdasarkan sifat - sifat tertentu dari tindakan dan perbuatan yang dilakukan. Bentuk deontologisme ada dua, yaitu: deontologisme tindakan, deontologisme peraturan.

c. Utilitarianisme, adalah jabaran dari kata latin utilis, yang berarti bermanfaat. Utilisme mengatakan bahwa ciri pengenal kesusilaan adalah manfaat suatu perbuatan. Ada dua bentuk utilitarianisme, yaitu: utilitarianisme tindakan, utilitarianisme peraturan.

d. Theonom, mazhab ini berpendapat bahwa kehendak Allah merupakan ukuran baik-buruknya suatu tindakan yang terbagi dua yaitu, teori theonom murni dan teori umum kodrat.

Etika secara umum dibagi menjadi sebagai berikut:

a. Etika umum, berbicara mengenai kondisi-kondisi dasar cara manusia bertindak secara etis, teori-teori etika dan prinsip-prinsip moraldasar yang menjadi pegangan bagi manusia dalam bertindak serta tolak ukur dalam menilai baik atau buruknya suatu tindakan. Etika umum dapat dianalogkan dengan ilmu pengetahuan, yang membahas pengertian umum dan teori-teori.

b. Etika khusus, merupakan penerapan prinsip-prinsip moral dasar dalam bidang kehidupan yang khusus. Penerapan ini bisa berwujud:Bagaimana saya mengambil keputusan dan bertindak dalam bidang kehidupan dan kegiatan khusus yang saya lakukan, yang didasari oleh cara, teori atau prinsip-prinsip moral dasar, bagaimana saya menilai perilaku saya dan orang lain dalam bidang kegiatan dan kehidupan khusus yang 
Page : 30-40

dilatarbelakangi oleh kondisi yang memungkinkan manusia bertindak etis? Cara bagaimana manusia mengambil suatu keputusan atau tindakan, dan teori serta prinsip moral dasar yang ada di baliknya.

Etika khusus dibagi menjadi dua bagian:

a. Etika individual, yaitu menyangkut kewajiban dan sikap manusia terhadap dirinya sendiri.

b. Etika sosial, yaitu berbicara mengenai kewajiban, sikap dan pola perilaku manusia sebagai anggota umat manusia. Perlu diperhatikan bahwa etika individual dan etika sosial tidak dapat dipisahkan satu sama lain dengan tajam karena kewajiban manusia terhadap diri sendiri sebagai anggota umat manusia saling berkaitan.

Etika adalah filsafat moral,atau ilmu yang membahas dan mengkaji secara kritis persoalan benar dan salah secara moral, tentang bagaimana harus bertindak dalam situasi konkret. Karena etika berkaitan dengan refleksi kritis, untuk menjawab pertanyaan, bagaimana kita harus bertindak dalam situasi konkret tertentu, ada tiga berbeda, yaitu :

- Etika Deontologi adalah lakukan apa yang menjadi kewajibanmu sebagaimana terungkap dalam norma dan etika deontology, suatu tindakan dinilai baik atau buruk berdasarkan apakah tindakan itu sesuai atau tidak dengan kewajiban.

- Etika teleology, berbeda dengan etika deontology. Dengan kata lain, etika teleology menilai baik buruk suatu tindakan berdasarkan tujuan atau akibat dari tinsakan tersebut. Teleology adalah pilihan tindakan yang membawa akibat baik.

- Etika keutamaan,

Berbeda dengan dua teori di atas, etika keutamaan tidak mempersoalkan akibat suatu tindakan. Etika keutaman lebih mengutamakan pengembangan karakter moral pada diri setiap orang.sebagaimana dikataka Aristoteles, nilai moral ditemukan dan muncul dari pengalaman hidup dalam masyarakat, dari teladan dan contoh hidup yang diperlihatkan oleh tokoh-tokoh besar dalam suatu masyarakat dalam menghadapi dan menyikapi persoalan-persoalan hidup.

\section{E. Etika Dan Kepemimpinan Birokrasi}

Alasan utama yang mendasari gagasan untuk menganalisis kepemimpinan birokrasi adalah masih banyak para pejabat pemerintahan yang menerapkan kepemimpinan "birokrasi transaksional Weberian". Sementara itu dihadapan mereka berbagai "permasalahan strategi: perlu sgera diselesaikan. 
Ability : Journal of Education and Social Analysis

Volume 2, Issue 3, Juli 2021

Page : $30-40$

Urgensi reformasi birokrasi semakin terasa apabila diingat bahwa iklim birokrasi kita saat ini masih diwarnai berbagai malpraktik yang berkembang dan membudaya selama 32 tahun era orde baru. Tidak meherankan jika stigma yang melekat pada birokrasi selama ini selalu identic dengan pelayanan public berkualitas rendah yang penuh korupsi, kolusi, dan nepotisme. Reformasi birokrasi semakin perlu dilakukan apabila dilihat bahwa budaya korupsi yang tumbuh subur selama era orde baru ternyata belum berakhir.

Menganalisis kondisi di atas semakin terasa urgensi reformasi birokrasi di Indonesia. Namun, saying sekali, sampai sekarang pemerintahan belum merumuskan suatu grand strategy terhadap reformasi birokrasi. Kita belum tahu langkah-langkah apa yang hendak ditempuh, bagaimana model birokrasi yang diharapkan, dan kapan program ini akan diselesaikan. Bebarapa program persial-seperti standar kompetensi jabatan dan diklat berbasis kompetensi, undang-undang pelayanan public, paradigm good governance-memang telah dirancang. Akan tetapi masih saja belum ada kejelasan tentang scenario yang akan dimainkan pemerintah dalam melaksanakan reformasi birokrasi. Tidak heran jika berbagai ahli dann praktisi menggagas berbagai konsep pembaharuan birokrasi. Mengingat sisi strategis fungsi pemimpin birokrasi sebagai penentu setiap kebijakan organisasi dalam mencapai setiap tujuan, perumusan suatu model kepemimpinan semacam itu sangat penting untuk keberhasilan tujuan reformasi.

a. Model Kepemiminan Birokrasi

Kepemimpinan birokrasi barangkali dapat didefinisikan sebagai suatu proses mempengaruhi para pegawai untuk menyelesaikan suatu pekerjaan, dan mengarahkan organisasi agar lebih kompak dan kondusif, dengan cara menerapkan konsep, nilai, etika, karakter, pengetahuan, dan ketrampilan melalui kewenangan yang dimilikinya. Legitimasi kewenangan ini pula yang digunakan Weber ketika menyusun model kepemimpinan birokrasi (Weberian).

1. Model Kepemimpinan Birokrasi Transaksional (Weberian)

Pada waktu mendiskusikan masalah organisasi, penggagas birokrasi Max Weber (1864- 1920) sebenarnya mengemukakan tiga model kepemimpinan, yaitu (1) kepemimpinan birokrasi, (2) kepemimpinan karismatik, dan (3) kepemimpinan tradisional. Pembagian model kepemimpinan ini didasarkan pada legitimasi pada implementasi kekuasaan dalam organisasi. Menurut Weber (1947), setiap pemimpin tentu memiliki salah satu di antara ketiga karakteristik kepemimpinan tersebut. 
Page : $30-40$

Kepemimpinan birokrasi transaksional model Weber ini pada umumnya memiliki karakteristik sebagai berikut:

a. Berdasarkan transaksi

b. Kejelasan aturan

c. Orientasi pada pengawasan yang ketat

d. Anti perubahan.

e. Orientasi pada jabatan dan kekuasaan:

f. Fokus pada pekerjaan

g. Kewenangan atasan mutlak.

h. Pemasungan kreatifitas pegawai.

i. Individualitas kerja

j. Disharmoni organisasi.

2. Model Kepemimpinan Birokrasi Transformasional

Konsep kepemimpinan transformasional pertamakali dikemukakan oleh James McGregor Burns pada tahun 1978, dan selanjutnya dikembangkan oleh Bernard Bass dan para behaviourists lainnya. Bass (1085) mendefinisikan kepemimpinan transformasional sebagai 'kemampuan yang dimiliki seorang pemimpin untuk mempengaruhi anak buahnya, sehingga mereka akan percaya, meneladani, dan menghormatinya.' Proses perubahan yang dilakukan pemimpin transformasional, menurut Bass, dapat dilakukan dengan cara: (1) meningkatkan kesadaran pegawai terhadap nilai dan pentingnya tugas dan pekerjaan; (2) mengarahkan mereka untuk fokus pada tujuan kelompok dan organisasi, bukan pada kepentingan pribadi; dan (3) mengembangkan potensi mereka seoptimal mungkin.

Berdasarkan diskusi di atas dan berbagai referensi, di bawah ini terangkum sepuluh prinsip kepemimpinan transformasi dalam lingkup birokrasi pemerintahan sebagai berikut:

a. Kejelasan visi

b. Kesadaran pegawai

c. Pencapaian visi

d. Pelopor perubahan

e. Pengembangan diri

f. Pembelajaran pegawai

g. Pemberdayaan pegawai

h. Pengembangan kreativitas

i. Budaya kerjasama

j. Kondusivitas organisasi 
Ability : Journal of Education and Social Analysis

Volume 2, Issue 3, Juli 2021

Page : $30-40$

\section{F. Urgensi Etika Dalam Birokrasi Politik}

Tujuan etika politik adalah mengarah ke hidup baik, bersama untuk orang lain. Dalam rangka memperluas lingkup kebebasan dan membangun institusiinstitusi yang adil (Paul Ricoeur, 1990). Defenisi etika politik ini membantu untuk menganalisis korelasi antara tindakan individual, tindakan kolekif, dan struktur-struktur yang ada. Pengertian etika politik dalam perspektif Ricoeur mengandung tiga tuntunan yaitu pertama, upaya hidup baik bersama dan untuk orang lain, kedua, untuk memperluas lingkup kebebasan, ketiga, membangun institusi-institusi yang adil.

Adapun dalam etika politik, yang merupakan etika sosial, untuk dapat mewujudkan pandangannya dibutuhkan persetujuan dari banyak pihak menyangkut tindakan kolektif. Maka, hubungan antara pandangan hidup seseorang dan tindakan kolektif tidak langsung membutuhkan perantaran, perantaran ini berfungsi menjembatani pandangan pribadi dengan tindakan kolektif. Perantaran ini bisa berupa simbol-simbolmaupun nilai-nilai, simbol agama, demokrasi, nilai keadilan, kebebasan, kesetaraan, dan sebagainya. Etika politik akan kritis terhadap manipulasi dan penyalahgunaan nilai-nilai dan simbol-simbol itu. Ia berkaitan dengan masalah srtuktur sosial, politik, ekonomi, dan budaya yang mengondisikan tindakan kolektif.

\section{G. Reformasi Birokrasi Dan Pengambilan Keputusan}

Tamin(2004) menjelaskan reformasi birokrasi adalah menyusun kembali struktur dan budaya kerja organisasi pemerintah dengan perspektif peningkatan kualitas dan pelayanan prima bagi masyarakat.

Menurut Thompson bobroknya birokrasi pemerintahan dalam menjalankan tanggung jawabnya dikarenakan para pembuat keputusan juga tidak memiliki etika dan moral yang baik dalam menjalankan jabatab publik. Teori birokrasi Weber adalah yang diterapkan di indonesia, bisa dilihat dengan struktur hierarkis disetiap birokrasi pemerintahan.

\section{KESIMPULAN}

Dalam pengambilan keputusan yang di ambil pemimpin ataupun pemerintahan tentunya akan menghasilkan dampak bagi semua orang. Idealnya, seorang pemimpin mempunyai integritas yang menjunjung tinggi nilai moral dan etika. Sehingga, dalam pengambilan keputusan yang diambilnya adalah mengacu tidak hanya pada kepentingannya sendiri, melainkan juga kepentingan untuk orang banyak termasuk lingkungannya. 
Ability : Journal of Education and Social Analysis

Volume 2, Issue 3, Juli 2021

Page : $30-40$

Ada lima keriteria dalam mengambil keputusan yang etis, yaitu utilitarian, universalisme, penekanan pada hak, penekanan pada keadilan, dan relativisme

\section{DAFTAR PUSTAKA}

Astiti. 2013. Etika Pendidikan Panduan bagi Guru Profesinal.

Danandjaja, J. (2014). Metode Penelitian Kepustakaan. Antropologi Indonesia, 52, 82-92. https:// doi.org/10.7454/ai.v0i52.3318

http://www.academia.edu/5781045/Rangkuman_Etika_Pendidikan/3juni202 1

Ismail, (2017), Etika Pemerintahan, Yogyakarta: Lintang Rasi Aksara Books.

Muhammad Rifa'I, (2020), Pengambilan Keputusan, Medan:Kencana.

Sari, M., \& Asmendri. (2020). Penelitian Kepustakaan (Library Research) dalam Penelitian Pendidikan IPA. Natural Science: Jurnal Penelitian Bidang IPA Dan Pendidikan IPA, 6(1), 41-53.

Zed, M. (2014). Metode Penelitian Kepustakaan. Pustaka Obor. 